\title{
THE IMPACT OF TECHNOLOGY HeLlo ENGLiSH APPLiCATION IN EFL ClaSSROOM
}

\author{
Ranta Butarbutar, Elia Simatupang \\ Universitas Musamus \\ ranta@unmus.ac.id
}

\begin{abstract}
Teaching English as foreign language in junior high school forced teacher to use technology as an interest media to attract student in learning. Primarily, an application was blasted off by Culture Alley in 2014; Hello English has the potential to solve student's problem of understanding simple past tense. The use of Hello English Application that gave significant impact in understanding simple past tense was the crucial intention of this study. In doing study, it used experimental and control class with 46 participants. This study proven that 1) there was significant difference of post-test between at experimental class; $95.6 \%$ and control class; $60.9 \%$ 2) Normality distribution figured out experimental group in post-test is $0.200>\alpha(0.05)$ and the significance value of control group in post-test is $0.051>\alpha(0.05)$. The significance values of both groups are higher than $\alpha(0.05)$. It means that $\mathrm{H} 0$ is accepted and $\mathrm{H} 1$ is refused. So, the test distribution of both two groups is normal 3) Homogenity test confirmed $\rho$ value (significant value) is higher than $\alpha$ value. $\mathrm{P}>\alpha, 0,955>$ 0,05 . Back to the hypothesis, $\mathrm{H}_{0}$ is accepted if $\rho>\alpha$. This means that the classes are homogeny 4) T-Test delighted 0.000 $<\square(0.05)$ for this reason $\mathrm{H} 0$ is rejected and $\mathrm{H} 1$ is accepted. This study conclude that the use of Hello English Application is an effective media in learning simple past tense; encouraging self-learning; changing towards gadget's better behaviour.
\end{abstract}

Keywords: impact, hello english application, simple past tense

\section{INTRODUCTION}

Teaching English as foreign language (TEFL) in Indonesia means that English has to be taught as a requirement in national curriculum. Clearly, this refers to the decision of ministry education and culture since 1967s, where English had become one of the compulsory foreign language taught in junior high school. Consequently, teacher or educator who involved in it should have variety of strategies, approaches, even media while teaching English. More importantly, educator has to do some activities before entering classroom in however she/he can presentate to the students in interesting manner. With attention to prepare lesson plan, to provide feedback, to prepare assessment and most importantly is learning media.

On the condition that students in revolution industry disruption 4.0 many activities will be changed by technology, with no exception to the learning system. Graddol (in Shyamlee \& Phil, 2012:1) states that technology lies at the heart of the process of globalization, influences the work and culture of education. Similarly (Anwar, 2016) states that in 21st century, teaching using some media that related to the technology is one of the innovations in teaching and learning. Teaching using conventional media has its own advantage in promoting the culture value, but in achieving better result, using the newest technology or platform such as android will give more advantage since it directly relates to the students daily life in this era.

Under those circumstances, many application technologies can be used as interest media to students, notably Hello English Application whatsapp group (Butarbutar, 2019), messenger, etc. Those applications can be accessed from personal gadget or android. This is alligned to the students who are fluent in gadget; they tend to spent time for gadget. On the positive side students are pretty famous and super handy to operate newest technology and to use up to date application. On the negative side, they are addicted to playing games. Considering this opportunity, the researcher has taken that gold opportunity to implement Hello English Application as an up to date media for teaching simple past tense at SMP N 2 Merauke.

Identically, (Cardini, Mayasari, Wijaya, \& SS, 2017) another study proven that hello English Application could help students in understanding simple present tense; concequently, improving their new vocabularies. Under those circumstances, they confirmed that Hello English Application could be as an alternative media in teaching simple present to students. By the same token (Klimova, 2018) declares that the use of smartphone in teaching English as Foreign Language (TEFL) was effective, improving students' vocabulary and encouraged motivation significantly. 
Initial research, (Putri, Mayuasti, \& Rahmadhani, 2018) assert that there are three problems by student of SMP N 22 Padang in understanding simple past tense, for instance 1) $60.525 \%$ had difficulties in the distinction ofs regular and irregular forms 2) there were $32.375 \%$ students doubted to differ from verbs between simple past tense and present perfect tense, lastly (3) there were $29.995 \%$ students doubted to fix time signal between past and present. Evidence that must be remembered was the 46 participant of this study. Uniquely, (Hidayati \& Diana, 2019) argue that the use of mobile Hello English Application could be motivate students independently outside of the classroom, since they could access it anywhere and anytime.

Recent study by (Satriani, 2019) recommends that the use of Hello English Application could serve as innovative media to amuse students in learning English. By the same token this application is effective to enrich students' vocabulary. Comparatively, while collecting data she interviewed some teachers in UIN University. It must be remembered that the teacher agreed to use Hello English Application was suitable to use in students classroom activities. However, the prior observation explored that $90 \%$ participants had difficulties in understanding simple past tense. To put it in another way, classic teaching style used by teacher made them felt bored while English activities occurred. Some students just presented filled attendant list.. It was proven that while teacher stood in front of class explained simple past topic seriously, the rest of the students seen glanced at their phone. Catching up this problem, this study chosen Hello English Application was the best solution for this case (Ekaningsih, 2017).

\section{MATERIALS AND METHODS}

\subsection{PARTICIPANTS}

This study covered by comparative design to see both experimental; using hello English Application and control group students that was taught not using hello English Application. Participants of this study consisted of 46 students in the seventh grade of SMP N 2 Merauke, Papua province.

\subsection{INSTRUMENTS}

To gather data or information, pre-test, action, post-test was conducted. Researcher had both class to do pre-test before giving treatment and post-test after giving treatment. In the light of (W Creswell, 2016) booked a post-test is used to measure the students ability in an experiment after given treatment.

\subsection{Data Analysis Procedures}

In analysing data gathered, this study used normality, the criteria of testing normality is if $\mathrm{P}$ value $>\sigma$ (sig. 0.05 ) so that $\mathrm{H} 0$ is accepted. But if $\mathrm{P}$ value $<\sigma$ so that $\mathrm{H} 0$ is rejected. $\mathrm{H} 0=$ Sample of data is normal distribution, $\mathrm{H} 1=$ Sample of data is not normal distribution. The criteria of the test based on $\mathrm{p}$ value as below:

$\mathrm{H} 0$ rejected, if $\mathrm{p}$ (value) $<\alpha$, so data is normal distribution; H1 Rejected, if $\mathrm{p}$ (value) $>\alpha$, so data is more normal distribution homogeneity., After the data distributed normally, it continued by examining Homogeneity test with using SPSS. Homogeneity has the function to check that 2 variables are the same or not. The criteria of testing homogeneity is if Ftabel $<$ Fcount reject $\mathrm{H} 0$ or Pvalue $<\alpha(5 \%=0.05)$. H0: $\alpha 12=\alpha 22$ there is no difference between experimental and control class, H1: $\alpha_{1} 2 \neq \alpha_{2} 2$ there is difference between experimental and control class.

In addition, the researcher also counted homogeneity using another way with calculating Fcount and Ftable. If Fcount $>$ Ftable, so H0 rejected, but if Fcount $<$ Ftable so that $\mathrm{H} 1$ rejected. Corespondingy, it used Eta Squared; According to Pallant (2007:236) there are three scale of this calculation, 0.01 is small effect, and 0.06 is moderate effect and 0.14 or above is large effect. In this research, the researcher adds Eta Squared to support T-Test. To count eta squared, the researcher uses the formula:

$$
\text { etasquared }=\frac{t^{2}}{t^{2}+\left(N_{1}+N_{2}-2\right)}
$$

The result of etasquared categorized refers to the table below:

\begin{tabular}{ll}
\hline Result & Category \\
\hline 0.01 & Low effective
\end{tabular}




\begin{tabular}{ll}
\hline 0.06 & Moderate \\
\hline 0.14 & Large effective
\end{tabular}

Table 1 result category (Harvey, 2009)

\section{RESULTS AND DISCUSSION}

Students' score were analysed by T-test; experimental class only $13 \%$ passed meanwhile control class achieved standard were 8\%. Data informed that the understanding both classes in using past tense classified as poor achievement, on the other hand far away from minimum standard achievement. In contrast, in post-test students got score passed significantly as $95.6 \%$ at experimental class, and $60.9 \%$ at control class, clearly shown as table 2 below:

\begin{tabular}{lllll}
\hline Interval scores & Percentage (\%) & Percentage (\%) & Percentage (\%) & Percentage (\%) \\
\cline { 2 - 5 } & Experiment class & Control class & Experiment class & Control class \\
\hline $51-100$ & 1 & 9 & $4.4 \%$ & $39.1 \%$ \\
\hline $50-0$ & 22 & 14 & $95.6 \%$ & $60.9 \%$
\end{tabular}

Table 2. students' score posttest

\subsection{HeLlo ENGLISH APPLICATION GIVING IMPACT SIGNIFICANTLY IN UNDERSTANDING SIMPLE Past Tense (SPT)}

Comparatively, there was difference between experimental class and control class after students got treatment (H0 was rejected). Based on the hypothesis, the null hypothesis is rejected and the substitute hypothesis is accepted if there is different score between experimental and control group after conducting the treatment. On the contrary, the null hypothesis is accepted and the substitute hypothesis is rejected if there is not different score between experimental and control group after conducting the treatment. To answer those hypotheses, the researcher does calculations using SPSS 25.0 software. Firstly, the researcher calculated the students' homogeneity both class whether the students' ability of both experimental and control groups are equal or not. The test was counted from the pre-test score among both classes.

Point often overlooked, the result has shown that both classes are homogeny or have the same characteristics. The second is measuring of normality distribution. The normality distribution is needed to know whether the sample represent the population or not. To test the data distribution is normal or not, the researcher uses Kolmogorov-Smirnov test with the hypothesis, $\mathrm{H}_{0}$ is accepted if $\rho$-value $>$ alpha ( $\alpha$ ) 0.05 and rejected $\mathrm{H}_{1}$ which means the data normality distribution. In the other hand, $\mathrm{H}_{0}$ is pushed away if $\rho$-value $<\alpha$, and accepted $\mathrm{H}_{1}$ which means this research is not normality distribution. The calculation shows that the result of pre-test score from both classes is significant. The $\rho$-value of experimental is 0,200 and control class is 0,051. So, $\mathrm{H}_{0}$ is accepted and the data is normality distribution. The third is measuring the effectiveness of hello English application for alternative media for teaching grammar using T-test. There some criteria of hypothesizes are:

The point one, criteria of hypothesis is to state the result of calculation from T-Test which stated $\mathrm{H}_{0}$ and $\mathrm{H}_{1}$ for knowing the media is effective or not. $\mathrm{H}_{0}$ : Hello English application is not effective as alternative media for teaching grammar. $\mathrm{H}_{1}$ : Hello English application is effective as alternative media for teaching grammar. The point two, criteria of hypothesis are the assessment standards that exist in the school and can be one of criteria that support the media used in the learning process is effective or not to be used as a learning media. Were the result on the criteria of looking at the students' post-test results in the experimental class has already affected the understanding of simple past tense in SMP Negeri 2 Merauke. The results indicate that the 11 students' post-test have exceeded the standard of assessment and the other student have exceeded the pre-test results. After the calculation the Eta Square, the value is 0,09. It means that the treatment give moderate effect to the post-test form. This number also supports the T-test result that substitute hypothesis is confirmed and the null is rejected. So the hello English application is effective for students' grammar mastery in learning. 
To put in another way, the researcher explained about the effectiveness of hello English application for the alternative media for teaching simple past tense (SPT), grammar beyond (Apsari Y, 2018). In accordance with the phrase of the creator of this application, Alley (2016) aims to make users of this application easier to learn English about grammar, vocabulary and pronunciation as well as many more benefits that can be obtained by its users. To say nothing of (Hidayati \& Diana, 2019) confirm that using mobile hello English Application might be raising students' motivation and independent way to learning English. By implementing vary technologies in learning English process are expected students to be hiring their own English competencies. Of course they could be flexible to fix attract application depend on interest their self. Coupled with etasquared category (table 1) study significantly declared that participants of this study got better scores than before. As an illustration, the Eta Square value is 0,09. Forthwith that treatment given at post-test class is categorized into moderate level. This number under those circumstances also supported of T-test result substitute hypothesis be confirmed and the null is rejected. By and large it helped students in learning SPT.

\subsection{HELlo ENGLISH APPLICATION ENCOURAGING SELF-LEARNING}

As mentioned that there was a significantly differences score both experimental and control class. Evidence must be remembered, refers to observation during research, they looked anthusiast tried to do exercise by their self both inside and outside classroom. Equally, it was proven the using this application made them spent their leisure time repeated task given by the teacher (Hidayati \& Diana, 2019). Comparatively, students in the gadget era are easier understood, econcentrate and even more motivated to do in case of doing by their gadget. As a matter of after getting score task given, student antusiast repeated it by himself without teacher's instruction but curious about scores given application itself. It was indicated that this application effective to encourage student to learn independently. On the other hand hello English application unconscious helps them increasing self-learning.

\section{CONCLUSION}

All things considered the information in previous study showed that the using hello English Application was an effective media in teaching English, simple past tense in particularly. Data findings and discussion proven 1) there was difference significantly of posttest between at experimental class; $95.6 \%$ and control class; $60.9 \%$ 2) Normality distribution figured out experimental group in posttest is $0.200>\alpha(0.05)$ and the significance value of control group in posttest is $0.051>\alpha(0.05)$. The significance values of both groups are higher than $\alpha(0.05)$. It means that $\mathrm{H} 0$ is accepted and $\mathrm{H} 1$ is refused. So, the test distribution of both two groups is normal 3) Homogenity test confirmed $\rho$ value (significant value) is higher than $\alpha$ value. $\mathrm{P}>\alpha, 0,955>0,05$. Back to the hypothesis, $\mathrm{H}_{0}$ is accepted if $\rho$ $>\alpha$. So it means that the classes are homogeny 4) T-Test delighted $0.000<\square(0.05)$ for this reason H0 is rejected and $\mathrm{H} 1$ is accepted.

As has been noted, no one media to claim is perfect even hello English Application. Researcher recognized the experience while implemented this aplication as media in teaching English at SMP N 2 Merauke pretty far from good competent (Butarbutar \& Ningsih, 2018). However it is implied to next productive and innovative researcher to do study about this media beyond. In the final analysis, by using hello English Application as media in teaching English as foreign language notwithstanding could be welcome new atmosphere in the classroom. In either case amused students and attract students interesting to learning English anymore.

Last but not least, technology potentials to improving students' motivation, vocabulary, and better scores in teaching learning process, English in particularly. Comparatively, research participants are productive young generation for future well. Educators or teachers have extreme responsibility to lead, to train, and to direct each student for using technology in a better motivation.

\section{REFERENCES}

Apsari, Y. (2018). Snowball throwing in teaching grammar. Lingual, 10(1), 52-59.

Butarbutar, R. (2019). The Study Impact of Whatsapp Group on Critical Reading Skill. Magistra: Jurnal Keguruan Dan Ilmu Pendidikan, 6(1), 45-51.

Butarbutar, R., \& Ningsih, T. B. (2018). Action Verbs-Based to Accustom Procedures Text. Musamus Journal of Language and Literature, 1(1), 11-20. 
Cardini, D., Mayasari, L., Wijaya, A., \& SS, M. P. (2017). The Effectiveness of Hello English Application 4th-6th and 9th-11th Lessons as the Alternative Media for Teaching Grammar in Seventh Graders in SMP Muhammadiyah 2 Surabaya. Universitas Muhammadiyah Surabaya.

Harvey, K. L. L. (2009). SPSS Survival Manual: A step-by-step guide to data analysis using SPSS version 15. Nurse Researcher, 16(3), 89-90.

Hidayati, T., \& Diana, S. (2019). Students' Motivation to Learn English using Mobile Applications: The Case of Duolingo and Hello English. JEELS (Journal of English Education and Linguistics Studies), 6(2), 189-213.

Klimova, B. (2018). Mobile phones and/or smartphones and their apps for teaching English as a foreign language. Education and Information Technologies, 23(3), 1091-1099.

Putri, R. J., Mayuasti, \& Rahmadhani, A. P. (2018). The Students Problem in Learning Simple Past Tense at SMPN 22 Padang. Jurnal Ilmiah Mahasiswa STKIP PGRI Sumatera Barat, (1). Retrieved from http://jim.stkip-pgri-sumbar.ac.id/jurnal/view/wgX9

Robert V. (2011). Children and Their Development (6th Edition) (Mydevelopmentlab Series). Englewood Cliffs, N.J: Prentice Hall.

Satriani, S. (2019). The Implementation of Hello English Application in Teaching Vocabulary. Universitas Negeri Makassar.

W Creswell, J. (2016). Research Design: Qualitative, Quantitative, Mixed Methods Approaches. University Of Nebraska-Lincoln. 
